\title{
Primary pericardial malignant mesothelioma: A rare but aggressive disease
}

\author{
Primer perikardiyal malign mezotelyoma: Nadir ancak agresif bir hastalık \\ Çağatay Arslan*, Saadettin Kılıçkap, Alev Türker
}

Department of Medical Oncology (Çağatay Arslan, MD), Tepecik Research and Training Hospital, TR-35200 Izmir, Department of Medical Oncology (Assoc. Prof. S. Kılıçkap, MD), Cumhuriyet University School of Medicine, TR-58140 Sivas, (Prof. Alev Türker, MD), Hacettepe University Institute of Oncology, TR-06100 Ankara

\begin{abstract}
Malignant mesothelioma of the pericardium is a rare disorder with a worse outcome compared to the pleural presentation of the disease. All treatment modalities are usually palliative. Here we report a patient with malignant mesothelioma of the pericardium presenting with severe dyspnea and pericardial effusion who survived only 2 months despite aggressive treatment.
\end{abstract}

Keywords: Malign mesothelioma, pericardium, chemotherapy

\section{Özet}

Malign perikardiyal mezotelyoma plevral mezotelyoma ile karşılaştırıldığında nadir ve daha kötü seyirli bir hastalıktır. Tüm tedavi uygulamaları genellikle palyatif kalmaktadır. Bu makalede ciddi dispne ve perikardiyal effüzyon ile seyreden ve agresif tedaviye rağmen sadece 2 ay yaşayabilen bir malign perikardiyal mezotelyoma olgusu sunulmaktadir.

Anahtar sözcükler: Malign mezotelyoma, perikard, kemoterapi

Geliş tarihi/Received: November 11, 2011; Kabul tarihi/Accepted: December 01, 2011

\section{*Corresponding Author:}

Dr. Çağatay Arslan, Tıbbi Onkoloji Bölümü, İzmir Tepecik Eğitim ve Araştırma Hastanesi, 35120 İzmir . E-mail: arslancagatay@yahoo.com

\section{Introduction}

Malignant mesothelioma of the pericardium is a rare disorder with a worse outcome compared to the pleural presentation of the disease [1]. Common clinical features of the disease include cardiac failure, pericarditis and/or tamponade. All treatment modalities are palliative, but in theory, surgery can be curative in a small number of patients with localized disease. Experience, gained from advanced malignant pleural mesothelioma, has shown that various chemotherapeutics have limited single agent activity. More recently, platinum based couplets have been reported to provide better response rates and survival benefit. Pemetrexed in combination with platinum drugs is the standard of care in malignant mesothelioma [2], though raltitrexed as well as gemcitabine have also been shown to be effective. Here we report a patient with malignant mesothelioma of the pericardium who presented with severe dyspnea and pericardial effusion and survived only 2 months despite aggressive treatment.

\section{Case report}

A 24-year-old man was referred to the outpatient clinic complaining of severe dyspnea and palpitation of 2 weeks duration. He had been diagnosed as having pericarditis at another hospital and was given anti-inflammatory drugs with no significant clinical 
improvement. Although the patient denied exposure to asbestos, he had lived in the southeastern part of Turkey, where the soil contains large quantities of asbestos, for about 10 years. His past medical history was unremarkable except for being a smoker. The only finding on physical examination was muffled heart sounds. Electrocardiogram revealed low voltage abnormality. He was admitted to the hospital for pending pericardial tamponade because of the fact that the amount of effusion had increased dramatically in the last 2 days. On his first day in hospital, the patient collapsed and a total of $800 \mathrm{ml}$ of hemorrhagic fluid was which proved to be positive for malignant cells drained from the pericardial space. Computerized tomography (CT) of the chest revealed pericardial effusion, increased pericardial thickness and enlarged prevascular lymph nodes (Fig. 1), while the abdominal scan was within the normal limits.

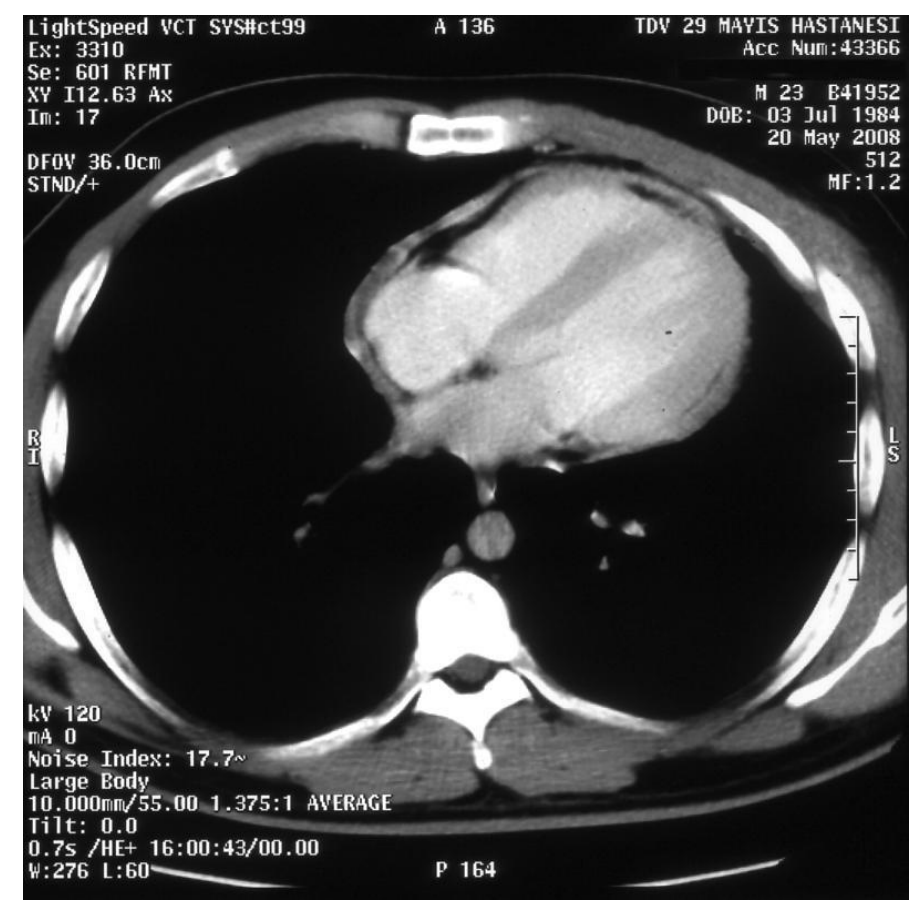

Figure 1. CT scan of primary pericardial mesothelioma after pericardial window procedure.

Due to rapid accumulation of pericardial fluid leading to clinical deterioration, a pleuropericardial window procedure was carried out. Biopsy, obtained at that time, revealed an undifferentiated malignant tumor infiltration suggestive of malignant mesothelioma (Fig. 2A-B).

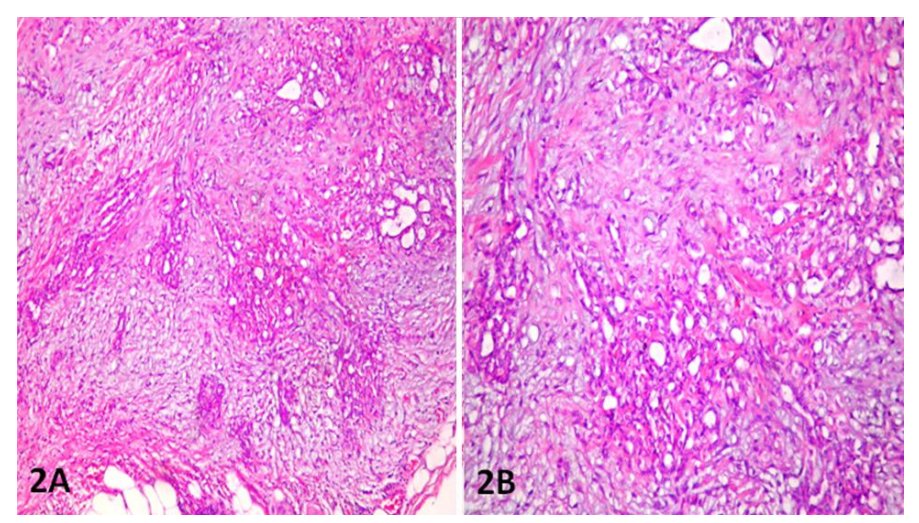

Figure 2A-B. Hematoxylin eosine staining of pericardial biopsy. A: X40, B: X200.

Due to the fact that surgery could be the only option for cure, a pericardiectomy with 
mediastinal lymph node dissection was performed. Unfortunately, a mass was seen to be invading the myocardium, and maximal debulking was performed. The histopathology confirmed epithelioid malignant mesothelioma, which stained positive for calretinin, HBME-1, WT-1, thrombomodulin and membranous EMA, and showed focal positivity for B72-3 and was negative for CEA, MOC-31 and cytokeratine 5-6. The patient could only receive one cycle of pemetrexed plus carboplatin, since the patient died only 2 months after diagnosis.

\section{Discussion}

The most frequent malignancy of the pericardium is metastatic disease from the other primary sites such as lung, breast, melanoma, lymphoma or leukemia [1]. Primary malignant pericardial mesothelioma accounts for 2-3\% of all primary cardiac tumors and less than $1 \%$ of all mesotheliomas [2]. However, about $50 \%$ of primary pericardial tumors are mesotheliomas [3]. In autopsy series, the incidence of mesothelioma was reported to be very low, $0.0022 \%$ [4]. Although there are reports suggesting radiation therapy as a causal factor for pericardial mesothelioma, etiology of the disease still remains unclear [6]. Exposure to asbestos has been related to the development of pleural mesothelioma, but, there seems to be no evidence to support a link between exposure and the development of pericardial mesothelioma [5, 7]. The case being presented had a history of living in an area where soil was contaminated asbestos, but, there was no finding suggestive of asbestosis in pathology. Patients with pericardial mesothelioma generally present with cardiac symptoms such as chest pain, dyspnea, palpitation or edema. Echocardiography, CT scan and magnetic resonance imaging of the chest are essential for the assessment of the disease. Similar clinical and radiological findings can be seen in benign conditions such as pericarditis related to tuberculosis. Differential diagnosis can be problematic especially in patients with abnormal chest X-rays [8]. This was the case in our patient. Cytology without immunocytochemistry may be inadequate in differentiating benign reactive mesothelial cells from malignant mesothelial cells. Surgical intervention such as a pericardial window procedure or pericardiectomy, when possible, could offer symptomatic relief for most and cure for the odd patient and sufficient sampling for the pathologist. Pericardial mesothelioma is a highly aggressive tumor and overall survival varies between 6 weeks to 15 months [1]. Treatment of the disease would hardly ever result in cure, but both local and systemic therapeutic options are used in concert or consecutively. Radical surgery is usually not possible but pericardiectomy is beneficial for the palliation of cardiac tamponade and pericardial constriction [9]. Being considered as a relatively radioresistant tumor, radiotherapy has not been proven to be very useful and may even be associated with unacceptable toxicity. Nevertheless, it can be a part of a multimodality treatment protocol especially for residual tumors following surgery. Due to lack of the data for pericardial mesothelioma, chemotherapeutic agents, used for treating the pleural presentation of the disease, are preferred. Drugs such as doxorubicin, vincristine and cyclophosphamide have limited single agent activity and may reduce the tumor burden [10]. A platinum drug with gemcitabine, raltirexed or pemetrexed might be options but at this time point, combination of a platinum drug with pemetrexed is the standard of care for pleural disease [3]. In a case reported from Japan, cisplatin with gemcitabine, and vinorelbine was shown to provide a 2 year progression-free survival [11]. Intracavitary use of cisplatin, for reducing fluid accumulation, may also prove to be effective [12]. The patient reported here had been diagnosed as having pericardial mesothelioma only after a pericardiectomy and was given a course of carboplatin and pemetrexed, but unfortunately he succumbed to the disease shortly thereafter.

Being a very rare disease limits the amount of information accumulated to date. For this reason it is important to report individual patient experience which may offer a chance of planning a multicenter trial in the upcoming future. 


\section{References}

1. Kralstein J, Frishman W. Malignant pericardial diseases: diagnosis and treatment. Am Heart J 1987; 113: 785-90.

2. Vornicu M, Arora S, Achilleos A. Primary pericardial mesothelioma: a rare cardiac malignancy. Internal Medicine Journal 2007; 37: 576-7.

3. Santos C, Montesinos J, Castaner E, Sole JM, Baga R. Primary pericardial mesothelioma. Lung Cancer 2008; 60: 291-3.

4. Gössinger HD, Siostrzonek P, Zangeneh M, Neuhold A, Herold C, Schmoliner R, Laczkovics A, Tscholakoff D, Mösslacher H. Magnetic resonance imaging findings in a patient with pericardial mesothelioma. Am Heart J 1988; 115: 13212.

5. Papi M, Genestreti G, Tassinari D, Lorenzini P, Serra S, Ricci M, Pasquini E, Nicolini M, Pasini G, Tamburini E, Fattori PP, Ravaioli A. Malignant pericardial mesothelioma. Report of two cases, review of the literature and differential diagnosis. Tumori 2005; 91: 276-9.

6. Small GR, Nicolson M, Buchan K, Broadhurst P. Pericardial malignant mesothelioma: a latent complication of radiotherapy? Eur J Cardiothorac Surg 2008; 33: 745-7.

7. Nilsson A, Rasmuson T. Primary pericardial mesothelioma: report of a patient and literature review. Case rep Oncol 2009; 2: 125-32.

8. Rose DS, Vigneswaran WT, Bovill BA, Riordan JF, Sapsford RN, Stanbridge RD. Primary pericardial mesothelioma presenting as tuberculous pericarditis. Postgrad Med J 1992; 68: 137-9.

9. Vigneswaran WT, Stefanacci PR. Pericardial mesothelioma. Curr Treat Options Oncol 2000; 1: 299-302.

10. Nambiar CA, Tareif HE, Kishore KU, Ravindran J, Banerjee AK. Primary pericardial mesothelioma: one-year event-free survival. Am Heart J 1992; 124: 802-3.

11. Maruyama R, Sakai M, Nakamura T, Suemitsu R, Okamoto T, Wataya H, Nishiyama K, Kamei $T$, Ichinose $Y$. Triplet chemotherapy for malignant pericardial mesothelioma: A case report. Jpn J Clin Oncol 2006; 36: 245-8.

12. Maisch B, Ristić AD, Pankuweit S, Neubauer A, Moll R. Neoplastic pericardial effusion. Efficacy and safety of intrapericardial treatment with cisplatin. Eur Heart J 2002; 23: 1625-31. 